\title{
Development of Augmented Reality (AR) Based Gamelan Simulation with Leap Motion Control
}

\author{
https://doi.org/10.3991/ijim.v13i12.9270 \\ Frihandhika Permana $\left({ }^{\bowtie}\right)$, Herman Tolle, Fitri Utaminingrum, Rizdania Dermawi \\ Universitas Brawijaya, Malang, Indonesia \\ frihandhikapermana@gmail.com
}

\begin{abstract}
One of the traditional musical instrument from Indonesia is gamelan, that is now less desirable because people nowadays prefer to play modern musical instruments, or because of its expensive price. This study combines the modern technology of AR and Leap Motion and also utilizes the sophisticated smartphone to develop a gamelan simulation that is presentable to the user. There are two kinds of an experiment performed in this research. The first is Augmented Reality (AR) experiment which authenticates that the distance and the height parameters are the keys to get a $100 \%$ success in running the gamelan simulation. The distance is ranged from $45 \mathrm{~cm}$ to $65 \mathrm{~cm}$ and the height is ranged from $25 \mathrm{~cm}$ to $30 \mathrm{~cm}$. And the second one is the usability evaluation to five users, who resolves the completion task very well, acquires the result of $86.48 \%$.
\end{abstract}

Keywords-Virtual instrument, hand gesture, traditional music, head mounted display (HMD)

\section{Introduction}

In 2018, the number of smartphone users today based on the survey has reached 2.53 billion [1]. The development of smartphone technology is now equipped with various sensors that allow it combined with other tools, such as Head Mounted Display (HMD) and Leap Motion. HMD is a computer display device or monitor, usually used to support the Augmented Reality (AR) and Virtual Reality (VR) technology. Some studies have conducted the implementation of HMD on a certain area, for instance, the HMD is used in the Android Application Controller using Internal Gyroscope Sensor [2] and also the HMD for activity recognition [3]. Augmented Reality (AR) is a system that is built by combining reality and virtual world. Leap Motion Controller is a small USB-based device that allows the user to control or play the computer by using motion [4], [5].

Gamelan is a traditional musical instrument from Indonesia. The term Gamelan consists of word "gamel" which menas to heat or to beat, and word "an" which makes it a noun [6]. So that the term Gamelan has a meaning as a unity of musical instruments played together. It consists of a set of instruments which have their own utilities but complement each other, which are Gong, Demung, Barung, Peking, and Slen- 
them [7]. Fig. 1 shows the picture of Gong and Fig .2 shows the picture of Demung. But nowadays, there are not many people understand about gamelan. The difficulty of getting gamelan musical instruments is because of the aspect of its scarcity and also because of it's highed-price.

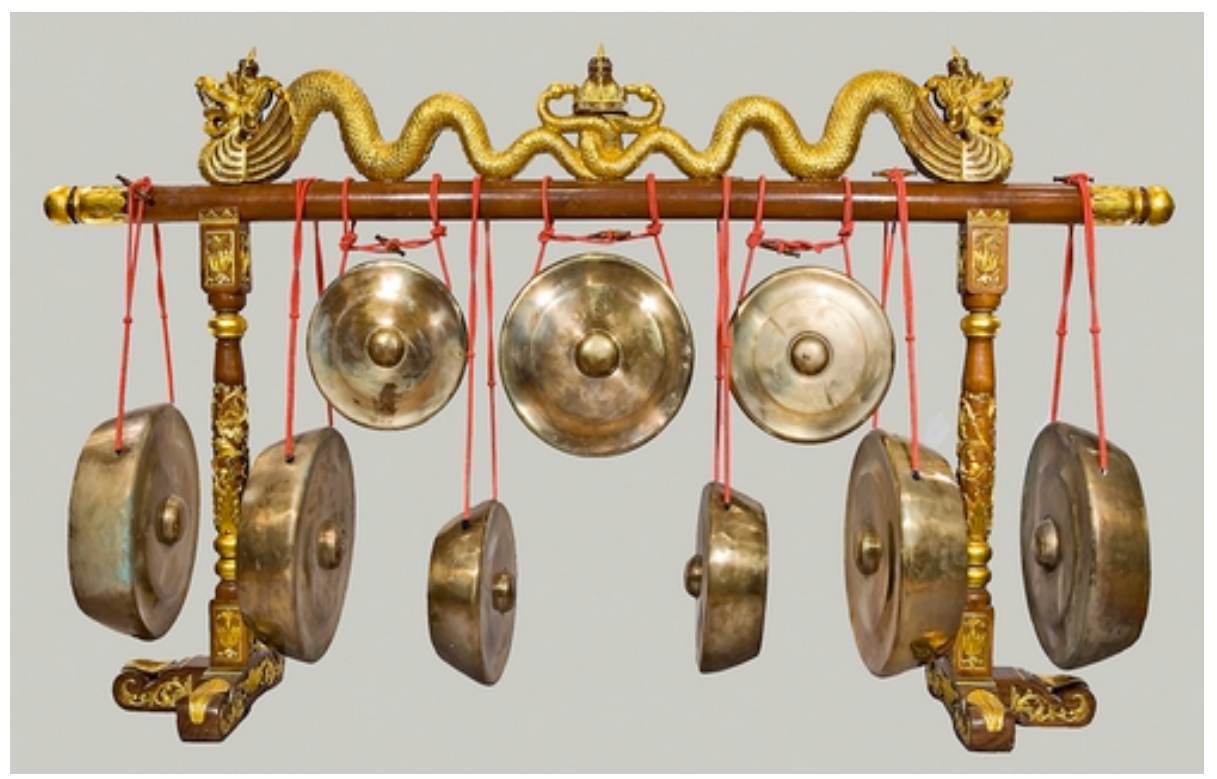

Fig. 1. Gong

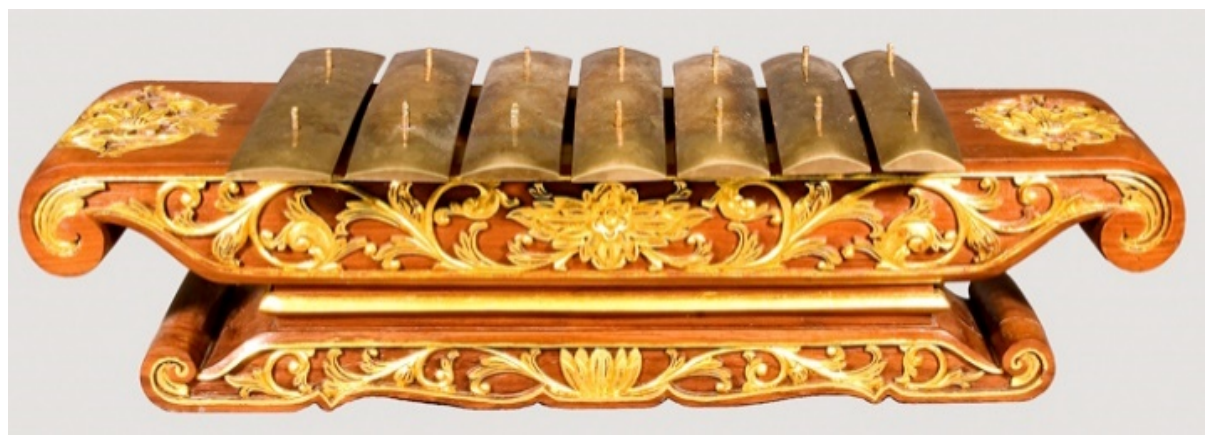

Fig. 2. Demung

Gamelan notes consist of the numbers that represent the note. Similar to general musical notes which also use numbers as representations of the names of the notes used, Table 1 describes the general musical notes and Table 2 shows the gamelan notes. 
Table 1. General Musical Notes

\begin{tabular}{|c|c|}
\hline Notes & Name \\
\hline 1 & Do \\
\hline 2 & $\mathrm{Re}$ \\
\hline 3 & $\mathrm{Mi}$ \\
\hline 4 & $\mathrm{Fa}$ \\
\hline 5 & So \\
\hline 6 & $\mathrm{La}$ \\
\hline 7 & $\mathrm{Ti}$ \\
\hline
\end{tabular}

Source: [6] (2003)

Table 2. Gamelan Musical Notes

\begin{tabular}{|c|c|c|}
\hline Notes & Short Name & Long Name \\
\hline 1 & $\mathrm{Ji}$ & Siji \\
\hline 2 & $\mathrm{Ro}$ & Loro \\
\hline 3 & $\mathrm{Lu}$ & Telu \\
\hline 4 & $\mathrm{Pat}$ & Papat \\
\hline 5 & $\mathrm{Mo}$ & Limo \\
\hline 6 & $\mathrm{Nem}$ & Enem \\
\hline 7 & $\mathrm{Pi}$ & Pitu \\
\hline
\end{tabular}

Although there were some studies that already discuss the gamelan simulation using AR technology, there is a big difference in the way of playing the simulation to the real one [8]. Based on the previously described background, this study is expected to introduce gamelan and how to play it similar to the real gamelan by utilizing AR and Leap Motion technology to smartphone users. This research has a purpose to develop the AR-based gamelan simulation with Leap Motion control, which is expected to have a decent accuration and performance. This gamelan simulation application is not only giving the Gamelan library of sounds an a visual impression of the intstruments, but it is also presenting the proper technique of playing gamelan through the simulation and also how to play the simulation that similar to how to play the real gamelan music instrument. So we can conclude that if we compare this gamelan simulation application to the application in the market that only provides the sounds library, this simulation is much better.

\section{Related Work}

Smartphone has already been used as musical instruments in some studies [9], [10]. In 2013, a study related to gamelan and Augmented Reality was conducted by [8]. The study evaluated the application to play gamelan musical instruments by using the marker as the virtual button. When the marker was covered, it meant that a note of the gamelan was played. but the app is not played similarly to the original gamelan. There was also a research into the use of Leap Motion for controlling traditional musical instruments. The Leap Motion detected the hand gestures above it and send the data to 
the computer as the signature for playing the musical instrument in the computer, but the shortcoming of this research is that it is desktop-based application [11]. In 2017, [12] conducted a study that uses Leap Motion as the Arabic sign language translator. The method used was Naïve Bayesian algorithms to classify 26 alphabets in sign language.

The research that evaluated the AR application with Leap Motion was also done by [4], [5], but they used the SDK alpha from the Leap Motion Corp. that the access cannot be downloaded and used by the developers anymore.

\section{Proposed Method}

\subsection{Storyboard}

In this research, the storyboard is meant for describing the flow of the gamelan simulation. The storyboard may show the whole idea of the system in a simple way [13]. The storyboard is in the form of images sequences that illustrates the relationship between the actions or inputs of the user and also the outputs of the system [14].

Fig. 3 describes the storyboard of the gamelan simulation system. The first step is connecting the Leap Motion to the computer as the server:

a) The Leap motion sends the data to the server

b) The server processes the data from the Leap Motion and sends it to the smartphone via the Wifi network

c) The user puts on the HMD with the Leap Motion and the smartphone are attached

d) The user sits in front of the marker, prepares to run the gamelan simulation

e) The image of the storyboard shows the user's after completing the previous stage

f) The image shows the perspective of the user when the gamelan simulation application detects the marker and it displays the 3D gamelan object

g) The image describes the user's perspective that is ready to play the gamelan simulation 


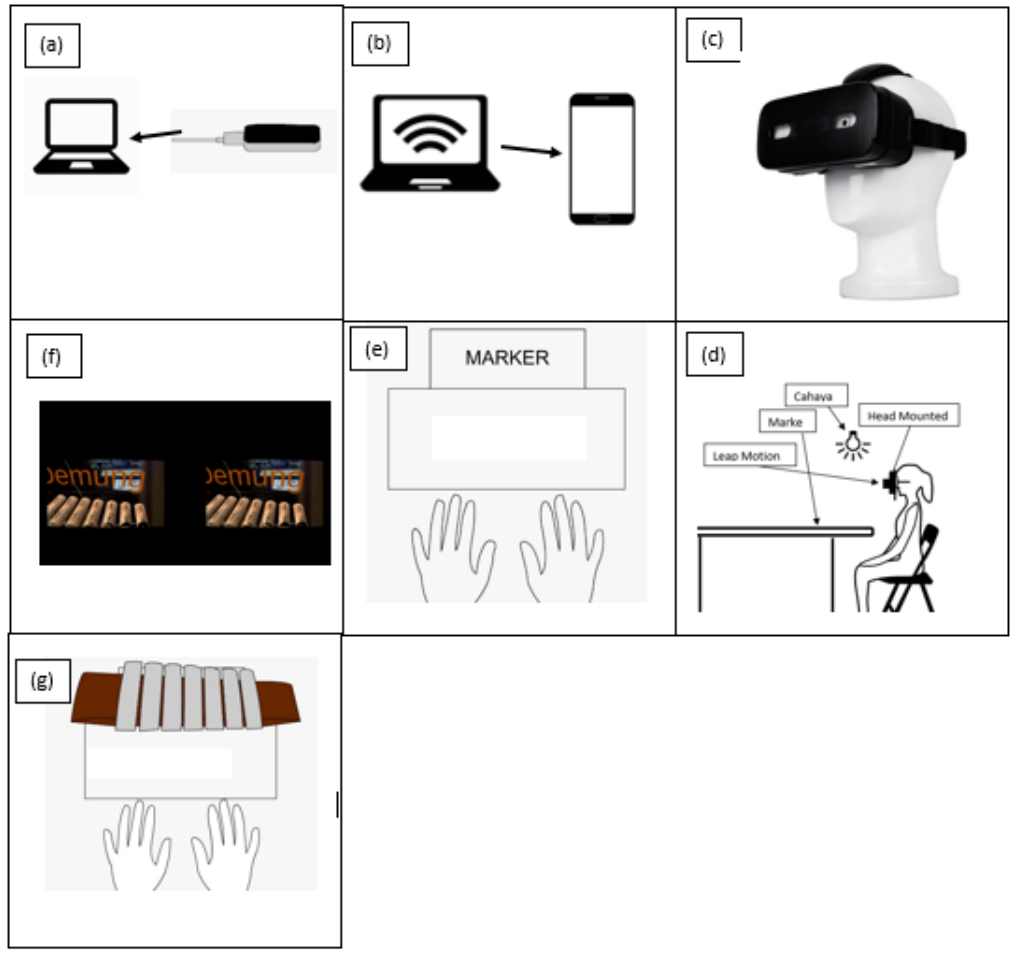

Fig. 3. Storyboard

\subsection{System architecture}

The system architecture in this study is shown in Fig. 4. The Leap Motion sends data to the server, then the server processes the data to be sent to the smartphone through the Wifi connection. The smartphone is attached to the Head-Mounted Display (HMD). 


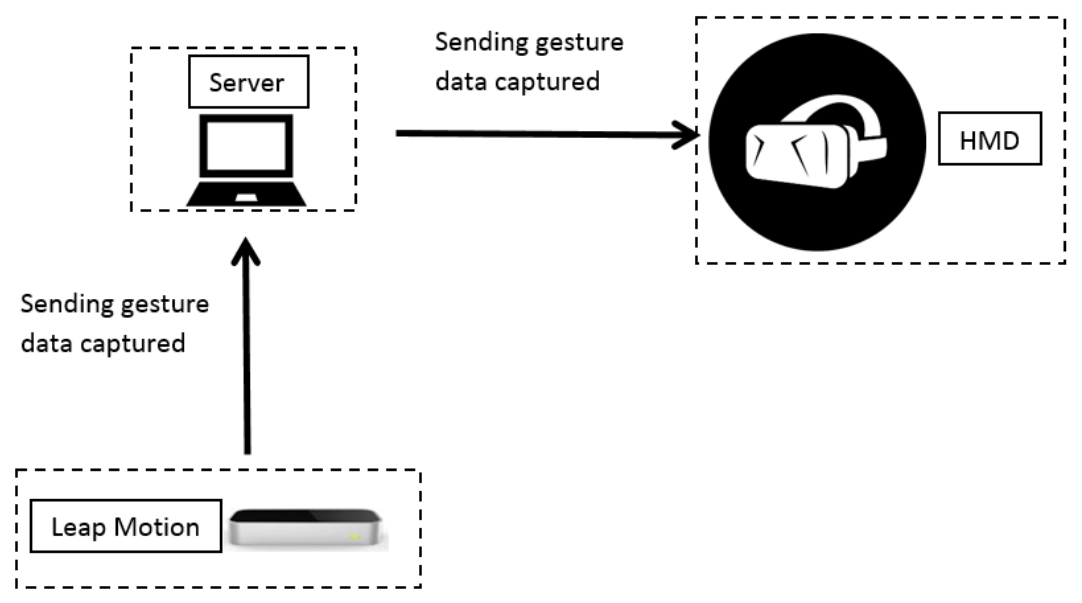

Fig. 4. System Architecture

\subsection{Server}

The server is used for receiving and processing the gesture data sent by Leap Motion. It also resends that data to the smartphone afterward. The server controls the 3D hammer that is used for striking the gamelan. The server application has some features, which are: screen and buttons. The server application preview is shown in Fig. 5.

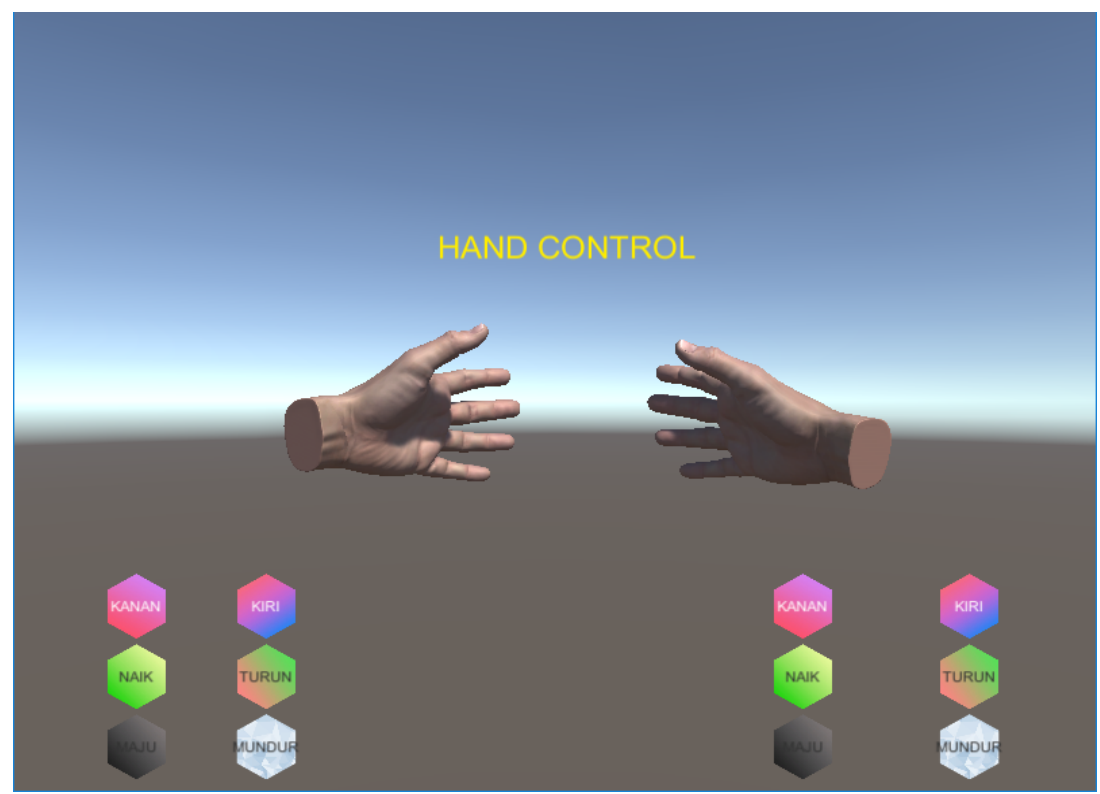

Fig. 5. The Server Preview 
The screen is for displaying the hand gesture captured by the Leap Motion. The buttons are used to adjust the hammer position in AR gamelan simulation $(\mathrm{x}, \mathrm{y}, \mathrm{z}$ positions). The buttons are divided into two groups; the buttons for arranging the lefthand position and for the right hand.

The use of this server application is to synchronize the network used by both devices which are the computer as the server and the smartphone that runs gamelan simulation.

\subsection{Implementation}

The AR-based gamelan simulation with Leap Motion control has some buttons for the user options in the Main Menu, those are Play, Library, Developer, Help, and Exit. The display of the main menu is shown in the following Fig. 6.

When the user picks the Play button, the application will go to the Play menu page with three buttons (a)

Saron button, Demung button, Back button.

Saron button and Demung button is the options for the user to play the AR gamelan simulation with Leap Motion controller.

The Library button carries the user to the Libray Menu which contains a brief description of the gamelan (b)

If the user wants to know the information about the gamelan simulation developer, they can choose the Developer button (c)

The Help button can be tapped if the user needs to figure out the description of how-to in the gamelan simulation application (d)

Fig. 7 shows the pages for the buttons in the main menu.

The recording process is done to record each tone from the musical instrument gamelan which will be used as a sample musical instrument that will be applied in the application of Augmented Reality-based gamelan simulation with Leap Motion control. This process is also making the results of the recording as an asset for the application of Augmented Reality-based gamelan controls with Leap Motion controller.

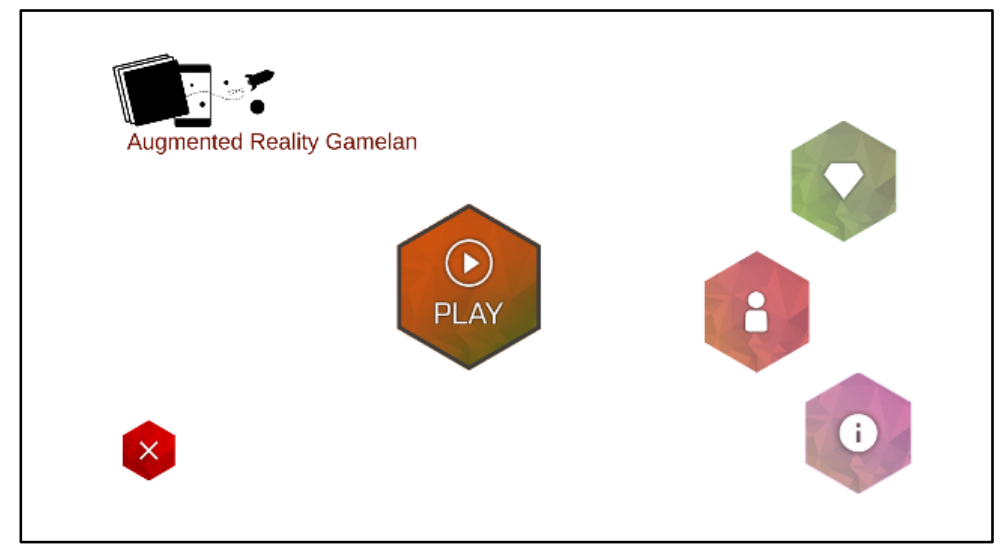

Fig. 6. The Display of Main Menu 
On the implementation process of gamelan simulation, Leap Motion connects to the server and captures the user's hand gesture data. The server receives that data from the Leap Motion and resends it to the smartphone through the wifi network. When the application scans the marker, it will render the 3D object of gamelan musical instrument. Fig. 8 is the user's perspective after the marker is detected. Fig. 9 shows the implementation of the gamelan simulation being played by a user.

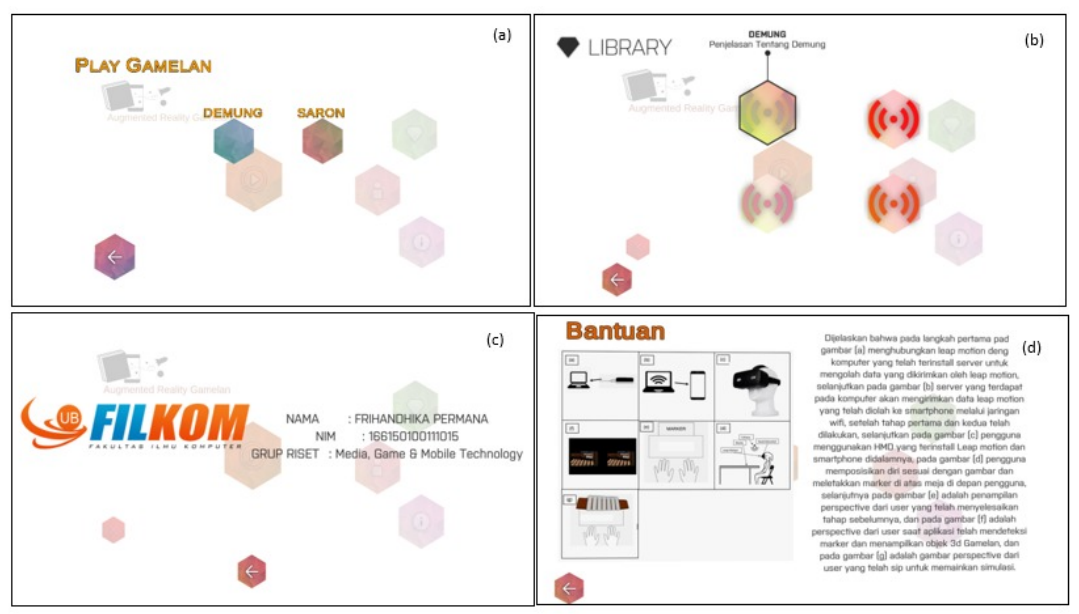

Fig. 7. The Display of the Menus in the Application

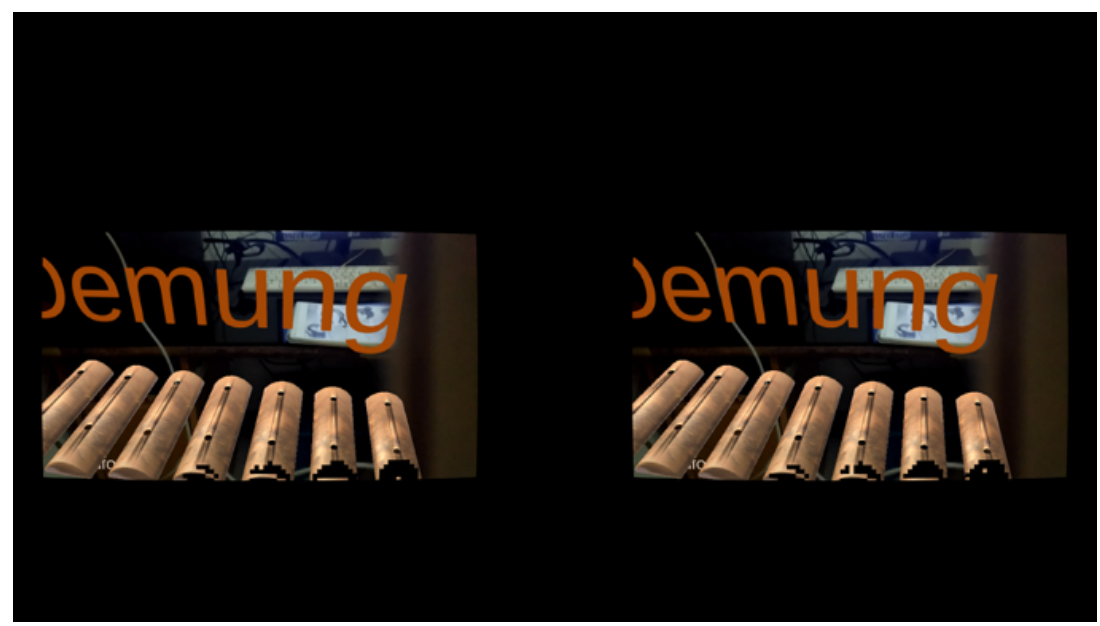

Fig. 8. The User's Perspective after Marker is Detected 

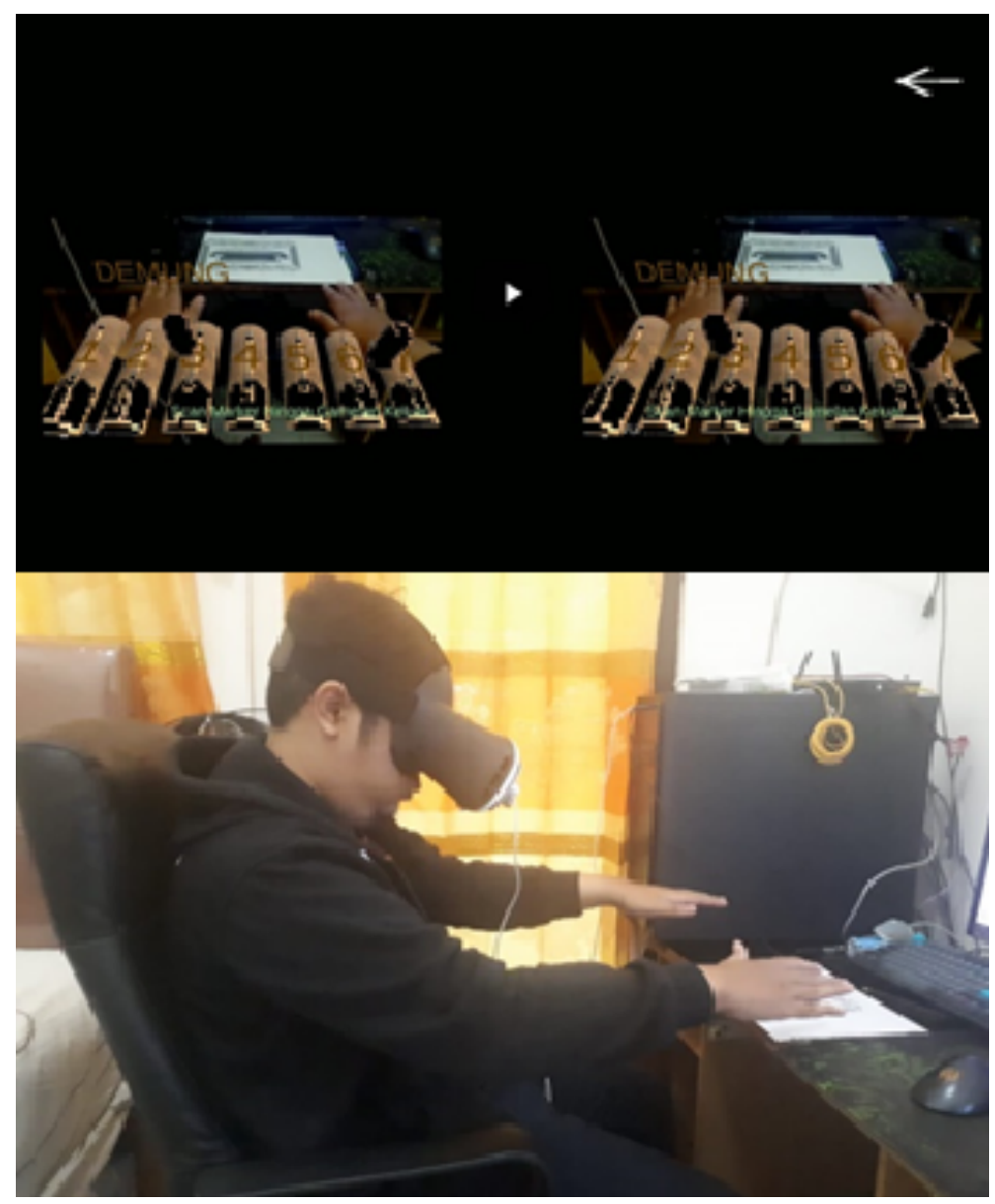

Fig. 9. The Implementation of the Gamelan Simulation

\section{Experimental and Analysis}

\subsection{Augmented Reality}

In this study, we have the Augmented Reality experiment which aims to measure and discover the essential parameters in this gamelan simulation. The experiments are held for some factors that are: the light, the distance, and the angle.

The Light Parameter: The light parameter experiment is meant to assure the light effect to the success of the application. By giving some different kind of light intensity, this experiment makes sure that different light condition will cause a certain result.

The user's perspective that seen in HMD is not affected by the light itself, because when the light intensity drops or gets lower, the preview on the smartphone display is adjusted to the proper light intensity to the user's vision. 
This experiment shows that the light intensity influences the process of the marker scanning. Even though there is low light intensity, but if the smartphone camera still can capture the marker, then the 3D gamelan object will still be able to be rendered in the simulation. Table 3 is the experiment result for the light parameter.

Table 3. The Light Parameter Experimental Result

\begin{tabular}{|c|c|c|c|}
\hline Light Intensity (lux) & Visible Marker & Rendered Gamelan & Status \\
\hline $50-56$ & $\checkmark$ & $\checkmark$ & Success \\
\hline $11-12$ & $\checkmark$ & $\checkmark$ & Success \\
\hline 9 & $\checkmark$ & $\checkmark$ & Success \\
\hline
\end{tabular}

The Distance and Angle Parameter: The distance and angle parameters are the factors that relate to each other because the angle is obtained from the angle that forms from the distance and the height of the HMD to the marker. Fig. 10 shows the position of the angle $\varnothing$, the distance and the height of to HMD in the experiment.

The calculation of is obtained by using the trigonometric formula shown in the following equation:

$$
\begin{gathered}
\tan \emptyset=\frac{\text { Height }}{\text { Distance }} \\
\emptyset=\tan ^{-1}\left(\frac{\text { Height }}{\text { Distance }}\right)
\end{gathered}
$$

This experiment is held for five users [15], they have to run the gamelan simulation at some determined distances and heights. In each trial, the results are noted and combined to calculate and acquire the users' success average in playing the simulation. The calculation of the success average obtained from the experiment is shown in following Table 4 and the graphics are shown in Fig. 11.

The highest (100\%) success average of is obtained in the experiment of distance 45 $\mathrm{cm}$ and height $30 \mathrm{~cm}$, the distance $50 \mathrm{~cm}, 55 \mathrm{~cm}, 60 \mathrm{~cm}, 65 \mathrm{~cm}$ and height $25 \mathrm{~cm}$ and $30 \mathrm{~cm}$. The calculation of the angle was achieved from the ration of the height and the distance of the HMD worn by the users. The experiment shows that the angle parameter is not the most significant influencing factor in the process of playing gamelan simulation. The range of the angle that allows users to play the simulation with $100 \%$ success average is between 21,097 o to 33,690 o.

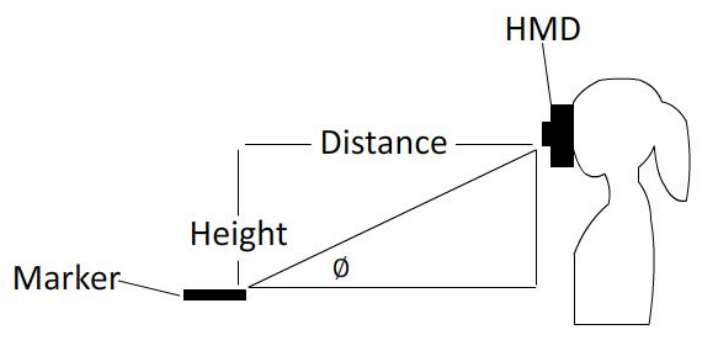

Fig. 10.The Position of the Angle $\emptyset$, the Distance and the Height of the HMD in the Experiment 
Table 4. The Success Average Result from the Experiment

\begin{tabular}{|c|c|c|c|c|c|c|c|c|}
\hline & \multicolumn{9}{|c|}{ Height (cm) } \\
\hline $\begin{array}{c}\text { Distance } \\
(\mathbf{c m})\end{array}$ & $\begin{array}{c}\text { Angle } \emptyset \\
(\boldsymbol{)})\end{array}$ & $\begin{array}{c}\text { Success } \\
\text { Average } \\
(\%)\end{array}$ & $\begin{array}{c}\text { Angle } \emptyset \\
\boldsymbol{(})\end{array}$ & $\begin{array}{c}\text { Success } \\
\text { Average } \\
(\%)\end{array}$ & $\begin{array}{c}\text { Angle } \emptyset \\
(\boldsymbol{\%})\end{array}$ & $\begin{array}{c}\text { Success } \\
\text { Average } \\
(\%)\end{array}$ & $\begin{array}{c}\text { Angle } \emptyset \\
(\boldsymbol{\%})\end{array}$ & $\begin{array}{c}\text { Success } \\
\text { Average } \\
(\%)\end{array}$ \\
\hline 40 & 20,556 & 33,33 & 26,565 & 33,33 & 32,005 & 66,67 & 36,869 & 66,67 \\
\hline 45 & 18,435 & 33,33 & 23,963 & 33,33 & 29,055 & 66,67 & 33,690 & 100 \\
\hline 50 & 16,699 & 33,33 & 21,801 & 33,33 & 26,565 & 100 & 30,964 & 100 \\
\hline 55 & 15,255 & 33,33 & 19,983 & 33,33 & 24,444 & 100 & 28,611 & 100 \\
\hline 60 & 14,036 & 0 & 18,435 & 33,33 & 22,619 & 100 & 26,565 & 100 \\
\hline 65 & 12,995 & 0 & 17,103 & 86,66 & 21,098 & 100 & 24,775 & 100 \\
\hline 70 & 12,098 & 0 & 15,945 & 79,99 & 19,654 & 93,33 & 23,199 & 66,67 \\
\hline 75 & 11,309 & 0 & 14,931 & 66,67 & 18,435 & 66,67 & 21,801 & 33,33 \\
\hline
\end{tabular}

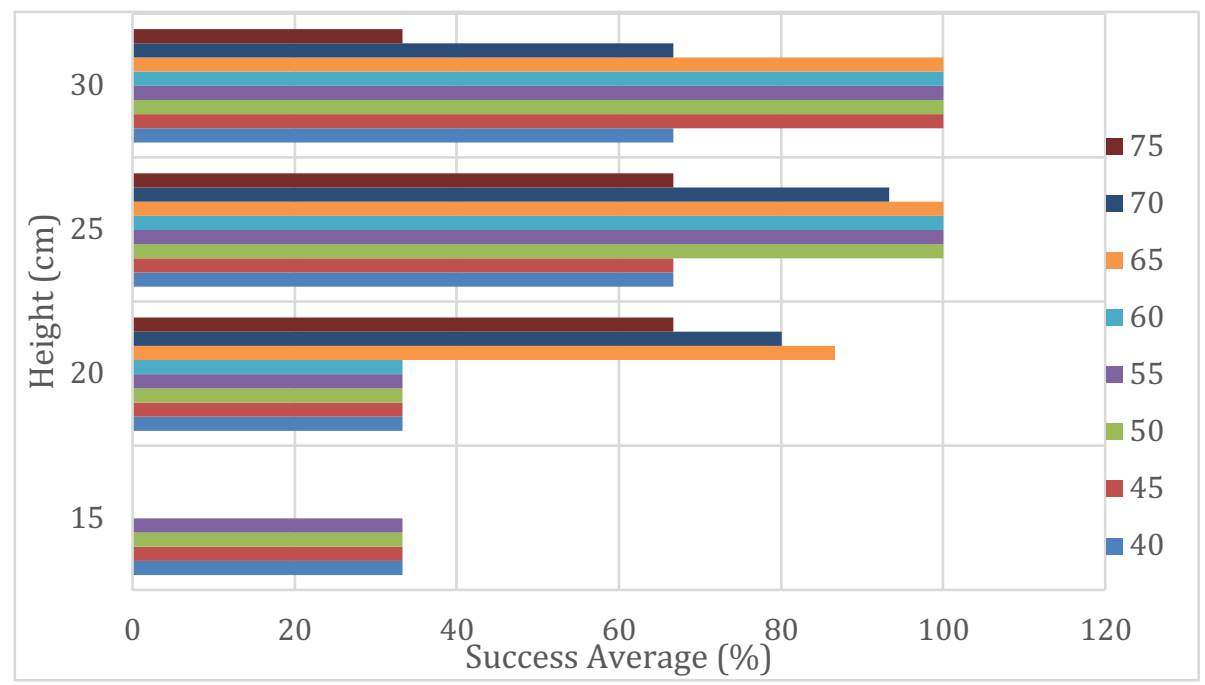

Fig. 11.The Graphic of Success Average Result from the Experiment

\subsection{Usability}

The usability evaluation for the AR-based gamelan simulation with Leap Motion control has five categories: Learnability, Memorability, Efficiency, Satisfaction, and Errors [16][17]. Some tasks are given to five users as they try to perform the gamelan simulation, as described in Table 5.

The user is given the questionnaire for each category, with a Likert scale for obtaining the result of the evaluation from 1 to 5 . The score for the answer is described in Table 6. Except for the Error category, that is by scoring the result of the task with maximum 100 points. The result of the questionnaire is presented in Table 7. 
Table 5. The list of the Task for the Users

\begin{tabular}{|c|l|}
\hline No. & \multicolumn{1}{|c|}{ Tasks } \\
\hline 1. & Open the application and pick the Demung Library page. \\
\hline 2. & Open the application and enter the Developer page. \\
\hline 3. & Open the application and play the Saron simulation. \\
\hline 4. & Strike the note 1 - 7 with the left hand \\
\hline 5. & Strike the note 1 - 7 with the right hand \\
\hline 6. & Open the application and play the Demung simulation \\
\hline 7. & Strike the note 1 - 7 with the left hand \\
\hline 8. & Strike the note 1 - 7 with the right hand \\
\hline 9. & Close the application by tapping the Exit button. \\
\hline
\end{tabular}

Table 6. The Score of the Answers

\begin{tabular}{|c|l|}
\hline Score & \multicolumn{1}{c|}{ Description } \\
\hline 5 & Strongly Agree \\
\hline 4 & Agree \\
\hline 3 & Neutral \\
\hline 2 & Disagree \\
\hline 1 & Strongly Disagree \\
\hline
\end{tabular}

Table 7. The result of the Questionnaire

\begin{tabular}{|c|c|c|c|c|c|c|c|}
\hline \multirow{2}{*}{ No. } & \multirow{2}{*}{ Statement } & \multicolumn{5}{|c|}{ Score } & \multirow{2}{*}{ Total Score } \\
\hline & & 1 & 2 & 3 & 4 & 5 & \\
\hline \multicolumn{8}{|c|}{ Learnability } \\
\hline 1. & $\begin{array}{l}\text { I think the AR-based gamelan simulation with Leap } \\
\text { Motion control is easy to play }\end{array}$ & 0 & 2 & 2 & 1 & 0 & 14 \\
\hline 2. & $\begin{array}{l}\text { I think the interface of the AR-based gamelan } \\
\text { simulation with Leap Motion control is easy to be } \\
\text { recognized }\end{array}$ & 0 & 0 & 2 & 2 & 1 & 19 \\
\hline 3. & $\begin{array}{l}\text { I think the page of the AR-based gamelan } \\
\text { simulation with Leap Motion control is easy to find }\end{array}$ & 0 & 0 & 0 & 2 & 3 & 23 \\
\hline 4. & $\begin{array}{l}\text { I think the text of the AR-based gamelan simulation } \\
\text { with Leap Motion control is easy to read }\end{array}$ & 0 & 0 & 0 & 1 & 4 & 24 \\
\hline 5. & $\begin{array}{l}\text { I think the icon of the AR-based gamelan simulation } \\
\text { with Leap Motion control is easy to understand }\end{array}$ & 0 & 0 & 3 & 2 & 0 & 17 \\
\hline \multicolumn{8}{|c|}{ Memorability } \\
\hline 1. & $\begin{array}{l}\text { I think I can recall the number of the notes of } \\
\text { Demung }\end{array}$ & 0 & 0 & 0 & 2 & 3 & 23 \\
\hline 2. & I think I can recall the number of the notes of Saron & 0 & 0 & 0 & 2 & 3 & 23 \\
\hline 3. & $\begin{array}{l}\text { I think I can recall the way to access the gamelan } \\
\text { simulation }\end{array}$ & 0 & 0 & 1 & 2 & 2 & 21 \\
\hline \multicolumn{8}{|c|}{ Efficiency } \\
\hline 1 & $\begin{array}{l}\text { I think the gamelan simulation can respond my hand } \\
\text { gesture very well }\end{array}$ & 0 & 0 & 1 & 2 & 2 & 21 \\
\hline 2 & I think the gamelan simulation is not lagging & 2 & 1 & 2 & 0 & 0 & 10 \\
\hline 3 & $\begin{array}{l}\text { I think the text appears in the gamelan simulation } \\
\text { provides enough information }\end{array}$ & 0 & 1 & 3 & 1 & 0 & 15 \\
\hline 4 & $\begin{array}{l}\text { I think the gamelan simulation helps me to get to } \\
\text { know gamelan }\end{array}$ & 0 & 0 & 0 & 2 & 3 & 23 \\
\hline
\end{tabular}




\begin{tabular}{|c|l|c|c|c|c|c|c|c|}
\hline 5 & $\begin{array}{l}\text { I think the gamelan simulation is reliable to help me } \\
\text { understand the way to play gamelan }\end{array}$ & 0 & 0 & 1 & 3 & 1 & 20 \\
\hline \multicolumn{7}{|c|}{ Satisfaction } \\
\hline 1. & $\begin{array}{l}\text { I feel comfortable to play the AR-based gamelan } \\
\text { simulation with Leap Motion control }\end{array}$ & 0 & 1 & 3 & 1 & 0 & 15 \\
\hline 2. & $\begin{array}{l}\text { I think the UI of the AR-based gamelan simulation } \\
\text { with Leap Motion control is interesting }\end{array}$ & 0 & 0 & 0 & 2 & 3 & 23 \\
\hline 3. & $\begin{array}{l}\text { I think the sound of the notes of the AR-based } \\
\text { gamelan simulation with Leap Motion control is } \\
\text { sounded clearly }\end{array}$ & 0 & 0 & 0 & 1 & 4 & 24 \\
\hline 4. & $\begin{array}{l}\text { I think the AR-based gamelan simulation with Leap } \\
\text { Motion control is interesting and attractive }\end{array}$ & 0 & 0 & 0 & 0 & 5 & 25 \\
\hline 5. & I think this gamelan simulation overall is satisfying & 0 & 0 & 2 & 2 & 1 & 19 \\
\hline
\end{tabular}

The result of the questionnaire is then calculated to get the criteria for each aspect of the usability as shown in Table 8 . After that, the result is processed to get the usability score, as seen in Table 9 [18].

The evaluation for the error aspect is obtained from the users' task completion. The maximum score is 100 . For the task number $1,2,3,6$, and 9 the score is either 0 or 100 (success $=100$, unsuccessful $=0$ ). Hence for the task number 4, 5, 7, and 8, the scores are obtained from the number of successes divided by 7 and multiplied by 100 . The result of the calculation is described in Table 10.

Table 8. The Calculation Each Aspect of Usability

\begin{tabular}{|c|l|c|c|c|c|c|c|}
\hline No & \multicolumn{1}{|c|}{ Usability Aspect } & $\mathbf{1}$ & $\mathbf{2}$ & $\mathbf{3}$ & $\mathbf{4}$ & $\mathbf{5}$ & Total \\
\hline 1. & Learnability & $0 \times 1$ & $2 \times 2$ & $7 \times 3$ & $8 \times 4$ & $8 \times 5$ & 97 \\
\hline 2. & Efficiency & $2 \times 1$ & $2 \times 2$ & $7 \times 3$ & $8 \times 4$ & $6 \times 5$ & 89 \\
\hline 3. & Memorability & $0 \times 1$ & $0 \times 2$ & $1 \times 3$ & $6 \times 4$ & $8 \times 5$ & 67 \\
\hline 4. & Satisfaction & $0 \times 1$ & $1 \times 2$ & $5 \times 3$ & $6 \times 4$ & $13 \times 5$ & 106 \\
\hline \multicolumn{2}{|l|}{ TOTAL } & $2 \times 1$ & $5 \times 2$ & $20 \times 3$ & $28 \times 4$ & $35 \times 5$ & 359 \\
\hline
\end{tabular}

After all the aspects are calculated, the usability average of the AR-based gamelan simulation with Leap Motion control can be enumerated, as seen in Table 11.

Learnability aspect obtains $77.6 \%$, efficiency aspect obtains $89 \%$, memorability aspect obtains $89.3 \%$, satisfaction aspect obtains $84.8 \%$ and error aspect obtain $91.7 \%$. The usability average of the AR-based gamelan simulation with Leap Motion control is $86.48 \%$. The graphic of the usability evaluation of the AR-based Gamelan Simulation with Leap Motion Control is described in Fig. 12.

Table 9. The Usability Score Result in Each Category

\begin{tabular}{|c|l|c|c|l|}
\hline No & Usability Category & $\begin{array}{c}\text { Total Score } \times \text { Likert } \\
\text { Score }\end{array}$ & Highest Score & \multicolumn{1}{|c|}{ Result } \\
\hline 1. & Learnability & 93 & 125 & $(97 / 125) \times 100 \%=77,6 \%$ \\
\hline 2. & Efficiency & 89 & 100 & $(89 / 100) \times 100 \%=89 \%$ \\
\hline 3. & Memorability & 67 & 75 & $(67 / 75) \times 100 \%=89,3 \%$ \\
\hline 4. & Satisfaction & 106 & 125 & $(106 / 125) \times 100 \%=84,8 \%$ \\
\hline
\end{tabular}


Table 10. The Error Aspect Usability Evaluation

\begin{tabular}{|c|c|c|c|c|c|c|c|}
\hline \multirow{2}{*}{ No. } & \multirow{2}{*}{ Task } & \multicolumn{5}{|c|}{ User } & \multirow{2}{*}{$\begin{array}{l}\text { Score } \\
(\%)\end{array}$} \\
\hline & & 1 & 2 & 3 & 4 & 5 & \\
\hline 1 & $\begin{array}{l}\text { Open the application and pick the } \\
\text { Demung Library page. }\end{array}$ & 100 & 100 & 100 & 100 & 100 & 100 \\
\hline 2 & $\begin{array}{l}\text { Open the application and enter the } \\
\text { Developer page. }\end{array}$ & 100 & 100 & 100 & 100 & 100 & 100 \\
\hline 3 & $\begin{array}{l}\text { Open the application and play the } \\
\text { Saron simulation. }\end{array}$ & 100 & 100 & 100 & 100 & 100 & 100 \\
\hline 4 & Strike the note $1-7$ with left hand & 100 & 85,714 & 57,143 & 100 & 71,429 & 83 \\
\hline 5 & Strike the note $1-7$ with right hand & 100 & 71,429 & 42,857 & 85,714 & 71,429 & 74 \\
\hline 6 & Open the application and play the ation & 100 & 100 & 100 & 100 & 100 & 100 \\
\hline 7 & Strike the note $1-7$ with left hand & 100 & 85,714 & 71,429 & 100 & 85,714 & 89 \\
\hline 8 & Strike the note $1-7$ with right hand & 100 & 71,429 & 57,143 & 100 & 71,429 & 80 \\
\hline 9 & $\begin{array}{l}\text { Close the application by tapping the } \\
\text { Exit button. }\end{array}$ & 100 & 100 & 100 & 100 & 100 & 100 \\
\hline \multicolumn{7}{|c|}{ 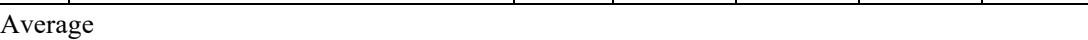 } & 91,7 \\
\hline
\end{tabular}

Table 11. Usability of the AR-based Gamelan Simulation with Leap Motion Control

\begin{tabular}{|c|l|c|}
\hline No. & \multicolumn{1}{|c|}{ Usability Aspect } & The result (\%) \\
\hline 1. & Learnability & 77,6 \\
\hline 2. & Efficiency & 89 \\
\hline 3. & Memorability & 89,3 \\
\hline 4. & Satisfaction & 84,8 \\
\hline 5. & Error & 91,7 \\
\hline Usability Average & 86,48 \\
\hline
\end{tabular}

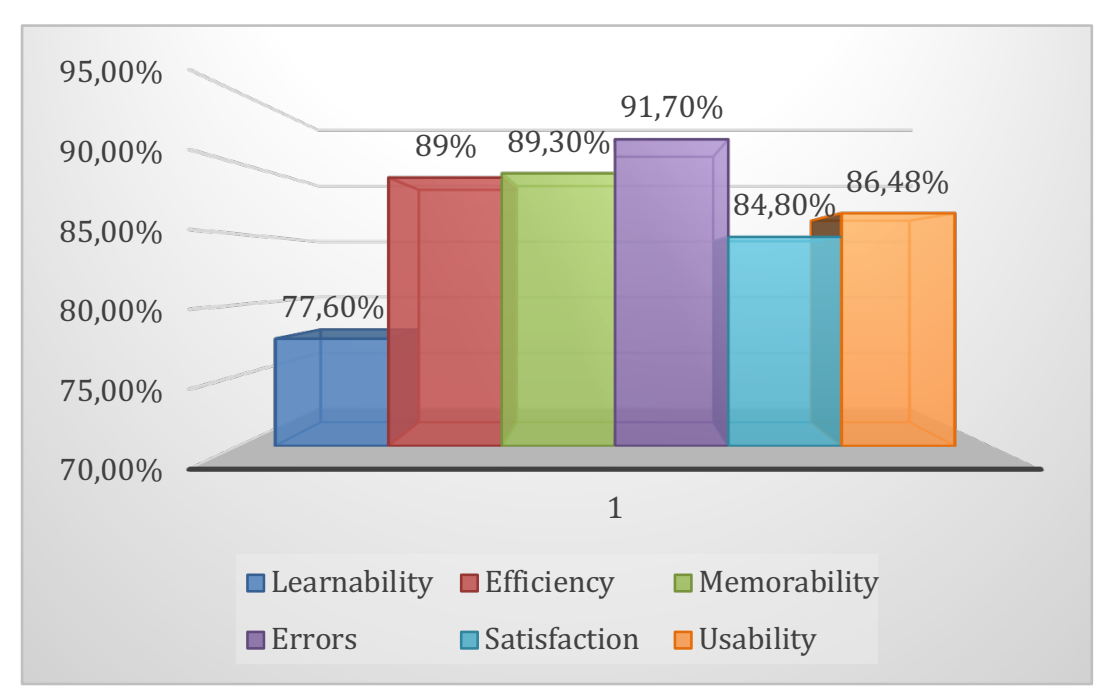

Fig. 12. Graphic of the Usability Evaluation of AR-based Gamelan Simulation with Leap Motion Control 


\section{Conclusion}

This research is about the AR-based gamelan simulation with Leap Motion control. For a $100 \%$ success in playing the gamelan simulation, the parameter of distance and height of the smartphone camera in the HMD to the marker is very important. The experiment verifies that the appropriate distance is from $45 \mathrm{~cm}$ to $65 \mathrm{~cm}$, and the height is from $25 \mathrm{~cm}$ to $30 \mathrm{~cm}$. From the experiment conducted, the lamp light does not affect the performance of the application if the lamp has a brightness from 9 to 56 lux.

The usability evaluation that applied to five users establishes that the highest aspect is $91.7 \%$ in error aspect. It shows that the users are able to carry out the completion task very well without making any significant mistakes. And the lowest score is $77.6 \%$ in learnability aspect. It is because the questionnaire was given to the users who are not familiar with the gamelan simulation. The average of the usability is $86.48 \%$ that is pretty much satisfying. The learnability improvement can be increase if the user was given the tutorial how to play the simulation before the user plays the gamelan simulation.

The traditional musical instrument gamelan can be introduced to the user to make it more familiar for them. The technology of AR and Leap Motion involved can be an allurement for the user that never try or know gamelan before.

The use of Augmented Reality can be increased by using the markerless. The next research Can use the official version of Leap Motion (if it has been released) to make the application more flexible and easy to use. The use of higher hardware smartphone specifications will make the application run more smoothly.

In the future, this study may emphasize improving the gamelan simulation into a better application. Whether the improvement of the response speed, the application's ergonomics, and the usability.

\section{References}

[1] Statista - The Statistics Portal, "Number of Smartphone Users Worldwide from 2014 to 2020 (in Billions)," 2018. [Online]. Available: https://www.statista.com/statistics/330695/ number-of-smartphone-users-worldwide/. [Ac-cessed: 18-Jul-2018].

[2] N. D. Priandani, H. Tolle, and F. Utaminingrum, "Real Time Advanced Head Move-ment Recognition for Application Controller Based On Android Internal Gyroscope Sen-sor," Int. J. Adv. Soft Comput. Its Appl., vol. 9, no. 1, 2017.

[3] F. Al Huda, H. Tolle, and R. A. Asmara, "Realtime Online Daily Living Activity Recognition Using Head-Mounted Display," Int. J. Interact. Mob. Technol., vol. 11-77, no. 3, p. 67-, 2017. https://doi.org/10.3991/ijim.v11i3.6469

[4] D. Huang, "Integration of Leap Motion Controller on Mobile Devices for AR Applications," New York, 2016.

[5] V. M. Sundaram, S. K. Vasudevan, C. Santhosh, R. G. K. B. Kumar, and G. D. Ku-mar, "An Augmented Reality Application with Leap and Android," Indian J. Sci. Technol., vol. 8, no. April, pp. 678-682, 2015. https://doi.org/10.17485/ijst/2015/v8i7/69907

[6] Sumarsam, Gamelan, Interaksi. Yogyakarta: Penerbit Pustaka Pelajar, 2003.

[7] N. W. Encyclopedia, "Gamelan," May 29, 2017. [Online]. Available: http://www.new worldencyclopedia.org/entry/Gamelan. [Accessed: 18-Jul-2018]. 
[8] S. J. Guntoro, T. A. S. Prasida, and R. Tanone, "Aplikasi Gamelan Menggunakan Virtual Buttons pada Teknologi Augmented Reality Berbasis Android," J. Teknol. Inf., vol. 10, no. 1, pp. 85-100, 2013.

[9] R. Michon, J. O. Smith, M. Wright, C. Chafe, J. Granszow, and G. Wang, "Mobile Music, Sensors, Physical Modeling, and Digital Fabrication: Articulating the Augmented Mobile Instrument," Appl. Sci., vol. 7, pp. 1-31, 2017. https://doi.org/10.3390/app7121311

[10] H. D. Ripley, "Untapped Revenue: Smartphones , A Smart Move for the Music In-dustry," University of Tennesee, Knoxville, 2012.

[11] R. R. Hariadi and I. Kuswardayan, "Design and Implementation of Virtual Indonesian Musical Instrument ( VIMi ) Application Using Leap Motion Controller," in 2016 International Conference on Information, Communication Technology and System (ICTS), 2016, no. VIMi, pp. 43-48. https://doi.org/10.1109/icts.2016.7910270

[12] T. Shanableh and A. Eqab, "Android Mobile App for Real-Time Bilateral Arabic Sign Language Translation Using Leap Motion," 2017 Int. Conf. Electr. Comput. Technol. Appl., pp. 1-5, 2017. https://doi.org/10.1109/icecta.2017.8251936

[13] A. Dix, J. Finlay, G. D. Abowd, and R. Beale, Human-Computer Interaction, 3rd ed. Pearson Prentice Hall, 2004.

[14] M. Maguire, "Methods to support human-centred design,” Int. J. Hum. Comput. Stud., vol. 55, pp. 587-634, 2001.

[15] J. Nielsen, "Why You Only Need to Test with 5 Users," Nielsen Norman Group, 2000. [Online]. Available: https://www.nngroup.com/articles/why-you-only-need-to-test-with-5users/. [Accessed: 08-Nov-2017].

[16] J. Nielsen, "Usability 101: Introduction to Usability," Nielsen Norman Group, 2012. [Online]. Available: https://www.nngroup.com/articles/usability-101-introduction-to-usab ility/. [Accessed: 08-Nov-2017].

[17] J. Nielsen, Usability Inspection Methods. New York: John Wiley \& Sons, 1994.

[18] R. Dermawi, H. Tolle, and I. Aknuranda, "Design and Usability Evaluation of Communication Board for Deaf People with User-Centered Design Approach," Int. J. Interact. Mob., vol. 12, no. 2, pp. 197-206, 2018. https://doi.org/10.3991/ijim.v12i2.8100

\section{$7 \quad$ Authors}

Frihandhika Permana is current as a Magister student in Faculty of Computer Science Brawijaya University, Malang, Indonesia. He is with the Research Group of Multimedia, Game and Mobile Technology, Informatics Department of Computer Science Faculty, Brawijaya University. (e-mail: frihandhikapermana@gmail.com).

Herman Tolle is with the Research Group of Multimedia, Game \& Mobile Technology, Faculty of Computer Science, Brawijaya University, Malang, Indonesia. (email: emang@ub.ac.id, herman.saga@gmail.com).

Fitri Utaminingrum is with the Research Group of Computer Vision, Faculty of Computer Science, Brawijaya University, Malang, Indonesia. (e-mail: f3 ningrum@ub.ac.id)

Rizdania Dermawi is current as a Magister student in Faculty of Computer Science Brawijaya University, Malang, Indonesia. She is with the Research Group of Multimedia, Game and Mobile Technology, Informatics Department of Computer Science Faculty, Brawijaya University. (e-mail: rizdaniadermawi@gmail.com).

Article submitted 2018-07-24. Resubmitted 2019-07-01. Final acceptance 2019-07-19. Final version published as submitted by the authors. 